\title{
Metallogenesis of Cobalt-bearing Mineralisation in the English Lake District
}

\author{
ADAM EDWARD ESKDALE ${ }^{1}$, AMY GOUGH ${ }^{1}$, DAVID \\ LOWRY $^{1}$, GIULIO SOLFERINO ${ }^{1}$ AND SEAN JOHNSON ${ }^{2}$ \\ ${ }^{1}$ Royal Holloway, University of London \\ ${ }^{2}$ Boliden \\ Presenting Author: adameskdale@btinternet.com
}

Cobalt is a critical metal needed for the development and production of future technologies, particularly within electric vehicles as part of Co-Li batteries. The key issue we currently face as a society is that cobalt, along with other designated Energy Critical Elements (ECE), is in increasingly short supply compared to demand. As the demand for cobalt rises across Europe, the security of global supply has never been more threatened. This is a result of the monopolisation of cobalt supply by few countries as well as current production being primarily as a by-product yield from base-metal sulphide deposits. To be able to prospect for new, economic grade cobalt deposits we must first understand the genesis of cobalt-bearing mineralisation in its varying styles. In support of this goal, the English Lake District, with numerous and varied Co-bearing ore, offers an excellent case study, within an easily accessible region, to build a generalized ore formation (i.e. metallogenetic) model.

Although all economic mining ceased in the Lake District by the 1990's, literature highlights several localities across the region that host As-Bi-Co bearing minerals. Recent investigation into Scar Crags and Dale Head North confirmed the presence of cobalt minerals at both areas, associated with As-Cu-Fe assemblages. However, to fully understand the genesis of cobaltbearing minerals in this region, more localities need to be investigated in greater depth. Ore-bearing fluid characteristics and emplacement conditions need to be defined, along with the expansion of current quantitative datasets on the mineral assemblages and their chemistries.

Ulpha, a locality in similar setting to Scar Crags and Dale Head North, has been investigated confirming As-Bi-Co-Cu minerals are present. However, the genesis of the cobalt-bearing minerals is still to be defined through mineral mapping on an SEM (BSE, EDS), followed by LA-ICP-MS and S isotope studies. Further localities (Coniston) are going to be investigated in a similar manner. This will be a comparative study between the mineralogy at Ulpha and Coniston with the other aforementioned localities (Scar Crags, Dale Head), providing a regional model to the controls on the ore emplacement. 